\title{
制振補強を施した既存鉄筋コンクリート造建築物の耐震診断法 A SEISMIC EVALUATION METHOD FOR EXISTING REINFORCED CONCRETE BUILDINGS RETROFITTED BY RESPONSE CONTROLLING TECHNICS
}

\author{
倉本 洋*, 飯場 正紀**, 和田 章***
}

Hiroshi KURAMOTO, Masanori IIBA and Akira WADA

\begin{abstract}
A seismic evaluation method for existing reinforced concrete buildings retrofitted by energy absorbing devices such as braces and stud columns with a damper is proposed in this paper. The proposed method is a static procedure to calculate the seismic index, $I_{s}$, for the buildings, which is an index to judge whether existing buildings and those retrofitted by conventional repair techniques are safe for the assumed earthquake load in the Building Standard Law of Japan. For three one-bay-one-story reinforced concrete frames with an energy absorbing device for which shaking table tests have been conducted, the $I_{s}$ values calculated by the proposed method is compared with those assumed from the test results in order to examine the validity.
\end{abstract}

Keywords : Seismic evaluation, Structural index, Existing RC buildings, Energy absorbing devices, Earthquake response control

耐震診断、構造耐震指標、既存 RC 建築物、エネルギー吸収デバイス、地震応答制御

\section{1. はじめに}

1995年1月の兵庫県南部地震による未曾有の建築物被害を契機 に、既存建築物の耐震性能の向上を図り、人命保護並びに財産保全 等を目的とした「建築物の耐震改修の促進に関する法律」（以下、 耐震改修促進法と略記）が同年12月に施行された1)。これにより、 公共建築物を中心にそれまでは希であった大規模建築物の耐震改 修が数多く行われるようになってきた。それに伴って、従来にない 新しい耐震補強技術の開発も活発化してきている2,3)。その中の一つ にエネルギー吸収性能に優れたダンパーを取り付けることにより、 既存建築物の耐震性能を向上させる、いわゆる制振補強法がある。 この方法は、従来のように既存建築物の強度や勒性を高める代わり に、付加したダンパーによって地震時に入力される振動エネルギー を効率的に吸収し、建築物の忘答変形を既存架構部分が破壊を起こ す変形以内に収め、地震による建築物の過大な損傷や倒壊を防止し ようとするものである。したがって、既存建築物自体の補強を最小 限に留めることができ、居ながら補強を可能にしたり、補強工事中 に生じる建築物の使用上の障害を軽減したりできることから、適用 事例も增えてきている4-6)。

これらの補強建築物の耐震安全性評価は、補強検討用の地震動を 用いた時刻歴応答解析結果に基づいて行われるのが一般的である。 一方、従来の強度型あるいは勒性型の補強方法を用いた場合には、 耐震診断基準等列えば7)の構造耐震指標（ $I_{s}$ 值）に基づく静的評価法 が用いられており、前述の耐震改修促進法においてもその方法が採
用されている。したがって、制振補強建築物の耐震安全性を確認す る方法として、従来型の補強建築物と同様な耐震構造指標に基づく 耐震診断法を利用できれば、耐震性の相互比較が容易となり、選択 した制振補強法の有効性も陽な形で評価できる。

そこで本研究では、エネルギー吸収デバイスにより補強された既 存鉄筋コンクリート（以下、RC と略記）造建築物に対する静的耐 震性能評価法 ( $I_{s}$ 值評洒法) を提案する。さらに、筆者らが実施し た振動台実験8)の結果から推定されるエネルギ一吸収デバイス補強 を施した実大の 1 層 1 スパン $\mathrm{RC}$ 造フレームの $I_{s}$ 值と、提案した評 価法により計算された $I_{s}$ 值を比較し、評価法の妥当性を検証する。

なお、提案する評価法は、地震時に柱あるいは耐震壁がせん断破 壊等の脆性的な破壊を生じる可能性のある既存 RC 造建築物に制振 補強を施したものを対象とする。

\section{2. エネルギー吸収デバイスを用いた補強建築物の構造耐震指標 $\left(I_{s}\right.$ 值) の評価法}

柱および而震壁の脆性破壞が問題となるような建築物を対象と すると、 $i$ 層における保有性能基本指標 $E_{o i}$ は次式で与えられる1)。

$$
E_{o i}=\frac{1}{A_{i}} \cdot \frac{Q_{u i}}{\sum_{j=i}^{N} w_{j}} \cdot F_{i}=D_{s} \cdot F_{e s} \cdot Z \cdot R_{t} \cdot C_{o} \cdot F_{i}
$$

ここに、 $A_{i}$ ：地震層せん断力伭数の分布係数

\footnotetext{
* 豊橋技術科学大学工学教育国際協力研究センター 助教授・ 工博

** 独立行政法人建築研究所構造研究グループ 上席研究員・工修

$* * *$ 東京工業大学建築物理研究センター 教授・工博
}

Assoc. Prof., International Cooperation Center for Engineering Education Development (ICCEED), Toyohashi University of Technology, Dr. Eng.

Chief Research Engineer, Structural Engineering. Group, Building Research Institute, M. Eng.

Prof., Structural Engineering Research Center, Tokyo Institute of Technology, Dr. Eng. 


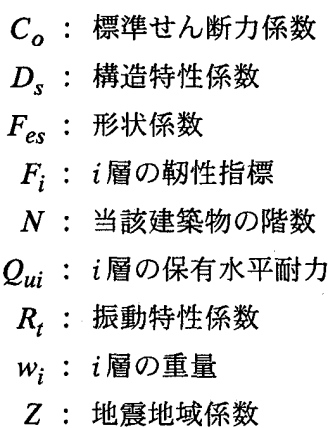

また、 $i$ 首における構造耐震指標 $I_{s i}$ は式(1)より次式で与えられる。

$$
I_{s i}=\frac{E_{o i}}{F_{e s} \cdot Z \cdot R_{t}}=D_{s} \cdot C_{o} \cdot F_{i}
$$

式(2)より、 $I_{s i}$ は想定する地震カレベル（標準せん断力係数 $C_{o}$ ) に対して建築物（あるいは層）が保有するエネルギ一吸収能力（強 度と変形能力の積）であると解釈できる（Fig.1）。ここで、以後の 議論を簡単にするために、式(2)における $D_{s} \cdot C_{o}$ および $F_{i}$ をそれぞ れ強度指棒 $C$ 值および勒性指標 $F$ 值とし、建築物の各階の值を代 表するものとする。

上記の解採によれば、建築物の耐震性能を向上させる場合には、 エネルギー吸収能力を高めるという観点から(1)保有水平耐力（すな わち、 $C$ 值) を高める、(2)勒性（すなわち、 $F$ 值）を高める、お よび(3)保有水平耐力と勒性を共に高める、等の方法が考えられる。

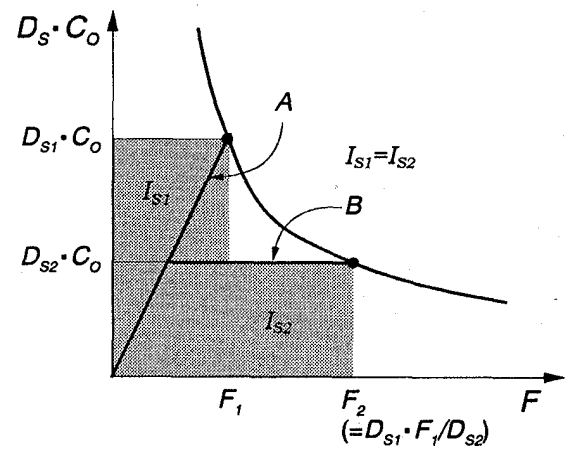

Fig.1 Strength Index, $D_{s} \cdot C_{o}$, versus Ductility Index, $F$, Relation

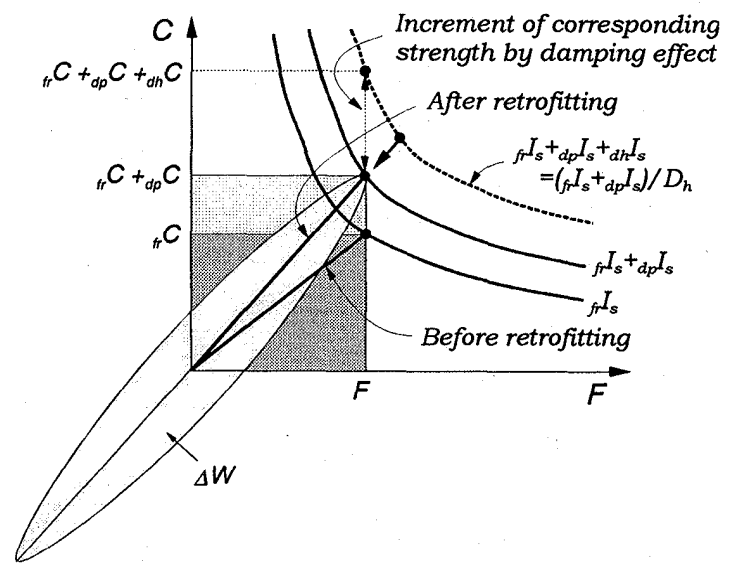

Fig. 2 Concept of Seismic Index of Structure, $I_{s}$, for Buildings Retrofitted by Energy Absorbing Devices
しかし、本研究で対象としているエネルギー吸収デバイスを用いて 建築物の地震時応答を制御する方法では、少なくとも(2)と(3)の勒性 を高める方法には当てはまらず、むしろ(1)の方法によってエネルギ 一吸収能力を高め、さらにデバイスにより履歴吸収エネルギーを增 加させる方法と位置付けることができよう。

そこで、Fig.2に示すような概念に基づいて、エネルギ一吸収デバ イスによって耐震補強を施した建築物の構造耐震指慗 $I_{s}$ が次式で 与えられるものと仮定する。

$$
\begin{array}{r}
I_{s}=\left({ }_{f r} I_{s}{ }_{d p} I_{s}\right) / D_{h}=\left({ }_{f r} C+{ }_{d p} C\right) \cdot F / D_{h} \\
\text { ここに、}{ }_{f r} C={ }_{f r} Q_{u} /\left(F_{e s} \cdot Z \cdot R_{t} \cdot A_{i} \cdot \sum w_{j}\right) \\
{ }_{d p} C={ }_{d p} Q_{u} /\left(F_{e s} \cdot Z \cdot R_{t} \cdot A_{i} \cdot \sum w_{j}\right)
\end{array}
$$

ここで、 $F$ は補強前の勒性指標、 $f r Q_{u}$ は補強前の保有水平耐力、 および ${ }_{d p} Q_{u}$ はエネルギ一吸取デバイスの $F$ 值に相当する変形で のせん断耐力をそれぞれ表す。なお、 $F_{e s} 、 R_{t} 、 A_{i}$ および $\sum w_{j}$ は それぞれ補強後の值を用いる。また、 $D_{h}$ は応答スペクトルに対す る減衰補正係数と類似した意味を持つ係数であり、次章で述べる補 強後の建築物の等価粘性減衰定数 $d p h$ を用いて式(6)で与えられる ものと仮定する。

$$
D_{h}=\frac{1.5}{1+10\left(\frac{d p}{h+0.05}\right)}
$$

式(3)は、デバイスによる履歴吸収エネルギーの効果を減衰補正係 数 $D_{h}$ による応答低減効果に読み替えて、補強後のエネルギ一吸収 能力 $\left(\left({ }_{f r} C+{ }_{d p} C\right) \cdot F\right)$ に対してその効果を考慮することによって 構造耐震指標 $I_{s}$ を評価しようとするものである。

\section{3. エネルギー吸収デバイスの負担せん断力と等価粘性減衰定数}

次に、エネルギー吸収デバイスの負担せん断力 ${ }_{d p} Q_{u}$ および補強 後の建築物における等価粘性減衰定数 ${ }_{d p} h$ の算定法を示す。なお、 以下では極低降伏点鋼（以下、LYP と略記）ダンパーおよび粘弾性 （同、VE）ダンパーを組み込んだデバイスについて検討するが、粘 性ダンパーを組み込んだデバイスについても、ダンパーに取り付く せん断力伝達材の弾性挙動を考虑すれば、粘弾性デバイスの場合と 同様な考え方が適用できる。

\subsection{LYPダンパーを用いたデバイスの場合}

LYP ダンパーを用いたエネルギー吸収デバイス（以下、LYPデバ イスと呼称）のせん断カー塑性率関倸をモデル化したものを Fig.3(a)に示す。また、同図(b)はその関係を強度指標一勒性指標関 係に変換したものである。同図(a)より、LYPデバイスの負担せん断 力 ${ }_{d p} Q_{u}$ は次式で与えられる。

$$
{ }_{d p} Q_{u}=\alpha_{d p} Q_{y}
$$

ここで、 ${ }_{d p} Q_{y}$ は LYP デバイスの降伏耐力であり、 $\alpha$ は LYP デ バイスが $F$ 值に相当する変形を生じた時の強度の降伏耐力に対す る比率で式(8)による。

$$
\alpha=1+\gamma\left({ }_{d p} \mu-1\right)
$$

ここで、 $\gamma$ は LYP デバイスの初期剛性に対する二次剛性の比率 

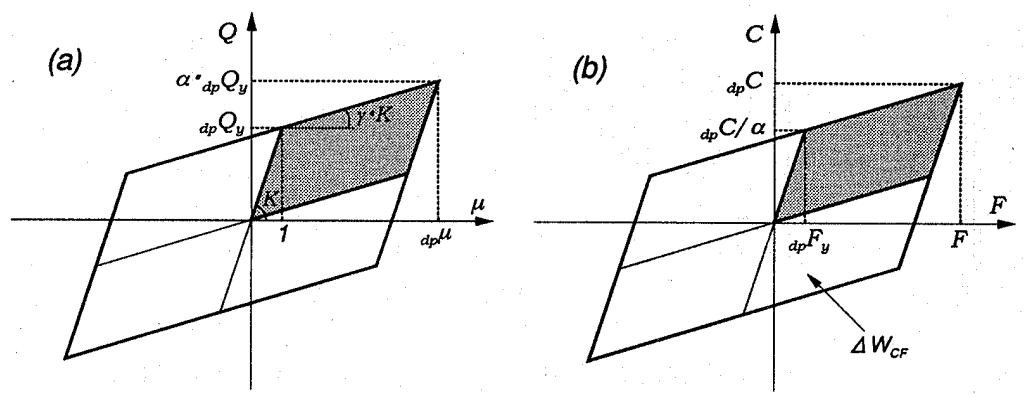

Fig. $3 Q-{ }_{d p} \mu$ and $C-F$ Relations of LYP Devices

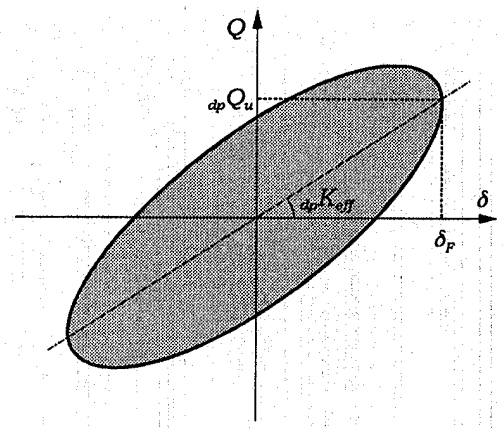

Fig.4 $Q-\delta$ Relation of VE Devices
（Fig.3(a)参照）および ${ }_{d p} \mu$ は LYP デバイスが $F$ 值に相当する変 形を生じた時の塑性率をそれぞれ表す。

ところで、 $\mathrm{RC}$ 造建築物における勒性指標 $F$ と塑性率 $\mu$ の関係は 次式で近似できる7)。

$$
F \approx \phi \sqrt{2 \mu-1}=\frac{1}{0.75(1+0.05 \mu)} \sqrt{2 \mu-1}
$$

本研究では、地震時に柱のせん断破壊等によって崩壊することが 懸念される既存 RC 造建築物に対してエネルギー吸収デバイスを用 いた耐震補強を行うことを想定しているので、補強前の各階の勒性 指標 $F$ は概ね0.8～1.27の範囲にあると考えてよい。すなわち、式 (9)において塑性率 $\mu$ は0.72〜 1.0程度となり、係数 $\phi$ は $1.27 \sim$ 1.29 程度となる。ここで、 $\mathrm{RC}$ 柱の (計算上の) 降伏変位を ${ }_{f r} \delta_{y}$ と し、 $\phi=1.29$ と仮定すると、 $F$ 值に相当する水平変位 $\delta_{F}$ は式(9) より略算的に

$$
\delta_{F}=\left\{(F / \phi)^{2}+1\right\}_{f r} \delta_{y} / 2 \approx\left(0.3 F^{2}+0.5\right)_{f r} \delta_{y}
$$

で与えられる。LYP デバイスの降伏変位を ${ }_{d p} \delta_{y}$ とすると、 $\delta_{F}$ の 変形を生じた時のデバイスの塑性率 ${ }_{d p} \mu$ は、

$$
{ }_{d p} \mu=\left(0.3 F^{2}+0.5\right)_{f r} \delta_{y} / d p \delta_{y}
$$

となる。したがって、式(7)、(8)および(11)よりLYPデバイスが F 值に相当する変形を生じたときの負担せん断力 ${ }_{d p} Q_{u}$ が得られる。

一方、LYP デバイスの等価粘性減衰定数 ${ }_{d p} h_{L Y P}$ は、デバイスの $C-F$ 曲線上で得られる履歴面積を $\Delta W_{C F}$ とすると、Fig.3 (a)およ び(b)における幾何学的関係より、

$$
{ }_{d p} h_{L Y P} \approx \frac{2}{\pi} \cdot \frac{d p \mu-\alpha}{\alpha \cdot d p} \mu=\frac{1}{4 \pi} \cdot \frac{\Delta W_{C F}}{d p C \cdot F / 2}
$$

となる。したがって、LYPデバイスで補強した建築物の等価粘性減 衰定数 ${ }_{d p} h$ は式(13)で与えられる。

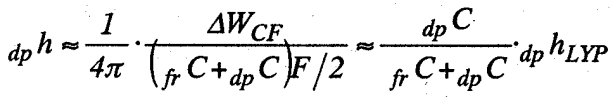

なお、式(13)は定常振動に対するものであるので、式(6)に用いる 際には過渡応答に対する影響を考慮して適切に低減する必要があ る。低隇方法としては、柴田等の Substitute Damping 9の考え方 等が参考になる。

\subsection{VE ダンパーを用いたデバイスの場合}

$\mathrm{VE}$ ダンパーを用いたエネルギー吸収デバイス（以下、VEデバイ スと呼称）のせん断カーせん断変形関係をモデル化したものを Fig.4に示す。VE ダンパーの場合、速度依存性が顕著であるので、 動的荷重下ではせん断力のピーク時とせん断変形のピーク時とが 一致しない。そこで、 VE デバイスのせん断耐力 ${ }_{d p} Q_{u}$ は等価剛性 ${ }_{d p} K_{\text {eff }}$ と式(10)で与えられる $F$ 值に相当する水平変位 $\delta_{F}$ によっ て次式で評価できるものとする。

$$
{ }_{d p} Q_{u}={ }_{d p} K_{e f f} \cdot \delta_{F}={ }_{d p} K_{e f f}\left(0.3 F^{2}+0.5\right)_{f r} \delta_{y}
$$

一方、VE デバイスで補強した建築物の等価粘性減衰定数 ${ }_{d p} h$ は $\mathrm{VE}$ デバイスの等価粘性隇衰定数 ${ }_{d p} h_{V E}$ によって、式(13) と同様に 次式で与えられる。

$$
{ }_{d p} h \approx \frac{{ }_{p p} C}{{ }_{f r} C+{ }_{d p} C} \cdot d p h_{V E}
$$

なお、上記3.1節および本節の検討では、エネルギー吸収デバイ スのせん断力ー塑性率関係（式(7)）、あるいはせん断力ーせん断変 形関係（式(14)）に基づいて議論を進めたが、これらの関係はダン パーのみのものではなく、せん断力伝達部材の弾性変形や周辺フレ 一ムの変形（間柱タイプのデバイスの場合における上下端梁の梁の 回転変形等）の影響が含まれたものである。したがって、実際に式 (7)および(12)、あるいは式(14)および(15)を用いてエネルギー吸収 デバイスの負担せん断力および等価粘性減衰定数を評価する場合 には、これらの影響を適切に考慮して関連パラメータを設定する必 要がある。

\section{4. 耐震性能評価法の検証}

本章では、LYP デバイスおよびVE デバイスによって補強された $\mathrm{RC}$ 造 1 層 1 スパンフレームの振動台実験の結果8)と比較すること により、上記の耐震診断手法の妥当性を検証する。なお、実験は Photo 1 に示す実験装置10,11)を用いて行われた。試験体は5層鉄筋 コンクリート造建築物の2階部分を模擬した実大 1 層1スパンで、Fig. 5 に示すような形状のものであり、柱は 1971 年以前の旧耐震基準に より再設計されている。また、使用した地震動は模擬地震動であり、 Taft EW (1952) 波の位相で、第二種地盤相当の $R_{t}$ スペクトルに フィッティングさせたものである。実験の詳細については文献8)に 譲ることとするが、本論では、Table 1に示す 4 試験体の実験結果 を用いて検討する。なお、同表には各試験体に対するエネルギー吸 


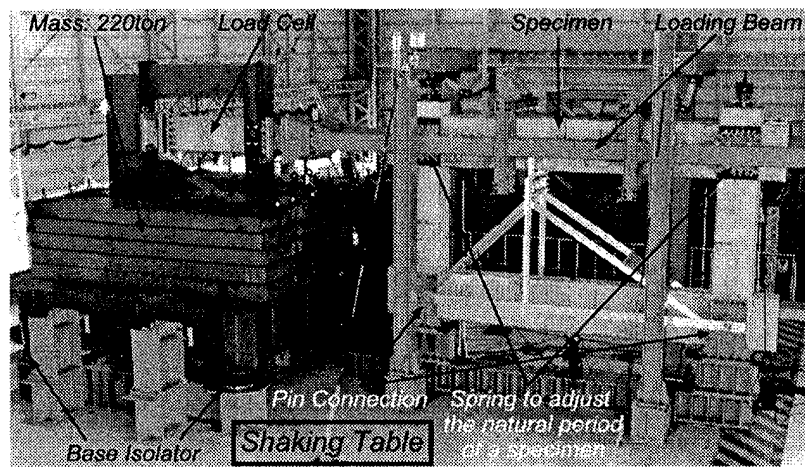

Photo 1 Loading Setup

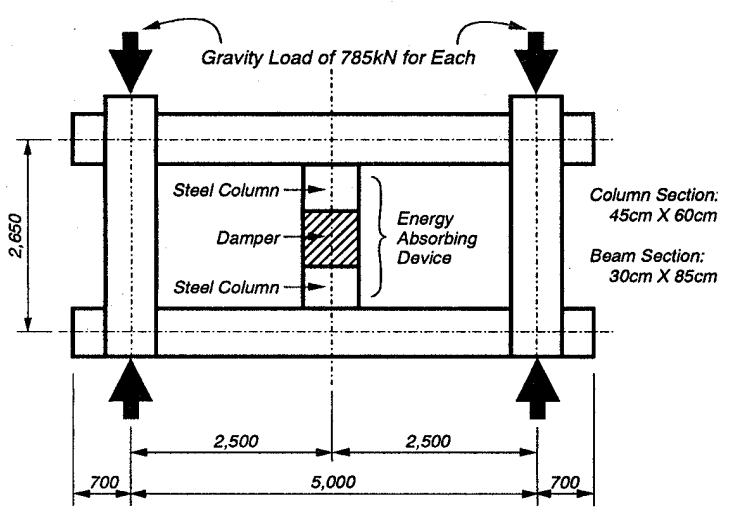

Fig. 5 Configuration of Test Specimens

Table 1 Test Plan

\begin{tabular}{c||c|c}
\hline Specimen & Input Level & Damper \\
\hline Bare Frame & 290 gal & ---- \\
\hline LYP Frame & 290 and $420 \mathrm{gal}$ & LYP \\
\hline VE-1 Frame & 290 gal & Visco Elastic \\
\hline VE-2 Frame & 290 and 420 gal & Visco Elastic \\
\hline
\end{tabular}

収デバイスの種類と入力地震動の最大加速度を併せて示している。 最大加速度290gal 入力の地震動に対して、無補強フレームでは 柱にせん断破䘫が生じたが、補強フレームでは何れの試験体もせん 断破壊に至っておらず、応答制御効果が確認された。また、最大加 速度420gal 入力の地震動では、補強フレームにおいても柱がせん 断破壊を生じた。

\section{1 実験結果から推定される補強フレームの $I_{s}$ 値}

地震動入力によって柱に脆性破壊が生じ、崩壊に至った試験体の 層せん断力ー層間変位関係を Fig.6に示す。同図(a)、(b)および(c) はそれぞれ無補強フレーム (290gal 入力)、極低降伏点ダンパー補 強フレーム（420gal 入力：以後、LYP 補強フレームと呼称）およ びゴムアスファルト系粘弾性ダンパー補強フレーム (420gal 入力 : 以後、VE-2補強フレームと呼称）に対するものであり、各試験体共 に崩壤後数秒までのデータを示している。なお、図中には灰色線で 破壊時近傍の等価剛性を示している。

無補強フレームでは、太線で示した正負 $25 \mathrm{~mm}$ 程度の繰り返しを 経験した後、剛性低下が顕著となり、-30mm 弱の変形で柱に付着

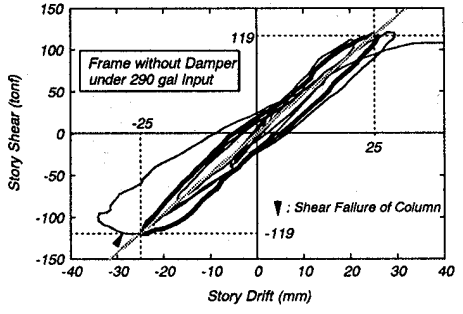

(a) Bare Frame (290gal)

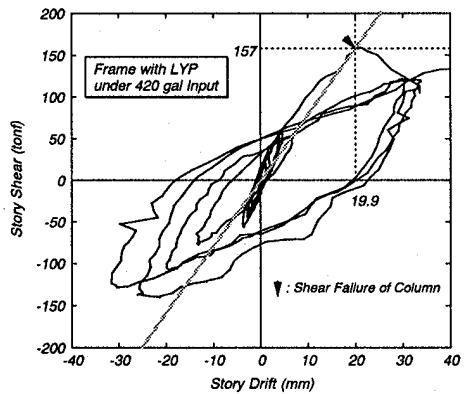

(b) LYP Frame (420gal)

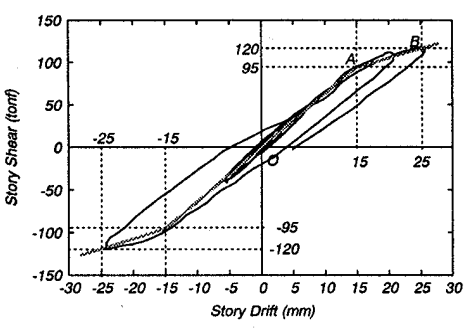

(a') Skeleton Curve of Bare Frame

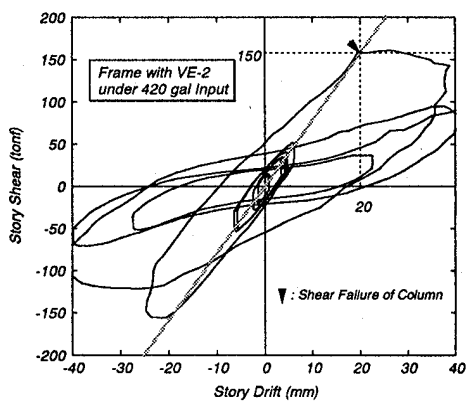

(c) VE-2 Frame (420gal)
Fig. 6 Story Shear versus Story Drift Relation for Collapsed Frames due to Excessive Input

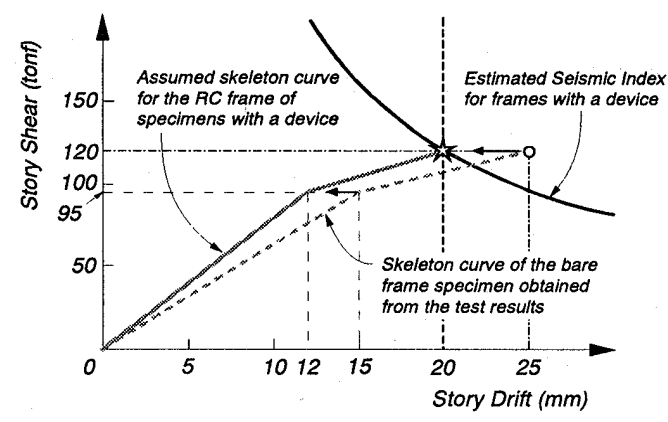

Fig. 7 Seismic Index Curve for 290 gal Input

割裂ひび割れを伴うせん断破壊が生じて崩壊に至っている (Fig.6(a)のV印)。したがって、無補強フレームの限界層間変位は $25 \mathrm{~mm}$ 程度と推定される。なお、Fig.6(a)には層間変位が $25 \mathrm{~mm}$ までの骨格曲線をモデル化したものを示している（図中の OAB）。

一方、ダンパー補強フレームでは、LYP 補強および VE-2補強共 に420gal 入力に対して $20 \mathrm{~mm}$ の層間変位で柱のせん断破壊を生じ ており、無補強フレームに比べて限界層間変位が小さくなっている。 この原因は、補強フレームではダンパーを取り付けるために設けた 間柱によって梁の剛性が増加したためと考えられる。したがって、 補強フレームの限界層間変位は約 $20 \mathrm{~mm}$ と推定される。

ここで、補強フレームにおける RC フレームの柱および梁主筋が 限界層間変位時に降伏していなかったことを考慮して、水平変位 $20 \mathrm{~mm}$ が $F=1.0$ に相当すると仮定すると、補強フレームにおける $\mathrm{RC}$ フレームの $I_{s}$ 值 (厳密には、 $I_{s}$ 值に慣性重量と限界層間変位を 乗じた值) は Fig.6(a')で仮定した無補強フレームの強度 (120tonf) と補強フレームの限界層間変位 (20mm) の積で与えられる（Fig.7 の々印)。したがって、それと等価な層せん断力と層間変位の組み 合わせである構造耐震指慗曲線（ $I_{s}$ 曲線）は Fig.7の太実線のよう 

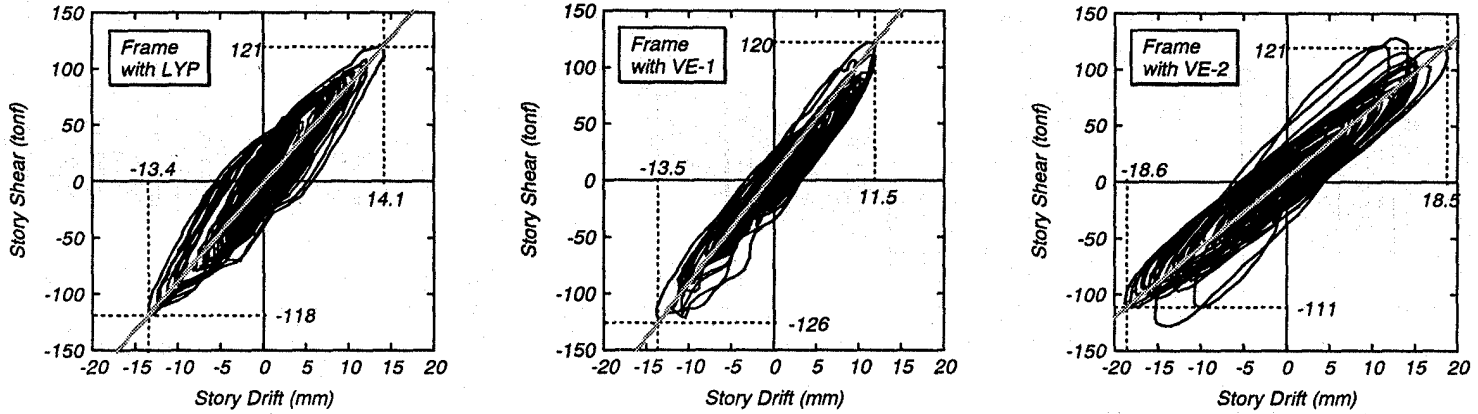

Fig. 8 Story Shear versus Story Drift Relation for Frames with Damper under 290 gal Input

Table $2 I_{s}$ Values Assumed from Test Results

\begin{tabular}{c|c|c|c|c|c}
\hline Specimen & $\begin{array}{c}\text { RC Frame } \\
{ }_{r} C\end{array}$ & $\begin{array}{c}\text { Device } \\
{ }_{d p} C\end{array}$ & $\begin{array}{c}\text { Damping } \\
{ }_{d h} C\end{array}$ & $I_{s \exp }$ & $D_{h \exp }$ \\
\hline \hline LYP & 0.545 & 0.109 & 0.300 & 0.954 & 0.686 \\
\hline VE-1 & 0.545 & 0.145 & 0.386 & 1.076 & 0.641 \\
\hline VE-2 & 0.545 & 0.005 & 0.068 & 0.613 & 0.890 \\
\hline
\end{tabular}

に描くことができる。

一方、入力最大加速度が290gal で、デバイスによる応答制御勃 果が確認された補強フレーム 3 体 (LYP補強、VE-1補強およびVE-2 補強）の層せん断力ー層間変位関係を Fig.8に示す。ここで、VE-1 補強フレームはジエン系ゴム粘弾性ダンパーを用いた試験体であ る。なお、図中には、Fig.6と同様に最大応答時における等価剛性を 灰色線で示している。何れの試験体も定常的な応答性状を示してお り、正負振幅における最大応答せん断力および変位の值に大きな差 異は認められない。ちなみに、最大応答変位の正負平均值は、LYP 補強、VE-1補強および VE-2補強フレームでそれぞれ $13.7 \mathrm{~mm} 、$

$12.5 \mathrm{~mm}$ および $18.5 \mathrm{~mm}$ となっている。

ここで、デバイスによる応答制御効果をせん断力に換算して応答 せん断力に付加したものを等唒せん断力 $Q_{e q}$ と定義すると、上記の 実験結果より、290gal 入力に対する各補強フレームの最大応答時 における $Q_{e q}$ は、最大応答変位の正負平均值に対応する值として $I_{s}$ 曲線上で求めることができる (Fig.9の黒印)。また、最大応答時 の $\mathrm{RC}$ フレームの負担せん断力 ${ }_{f r} Q$ は、Fig.7で求めた骨格曲線上 で与えられる (Fig.9の白印)。したがって、最大応答時のデバイス の負担せん断力 ${ }_{d p} Q$ および減衰効果による見かけの負担せん断力 ${ }_{d h} Q$ （Fig.2における ${ }_{d h} C$ に重量を乗じたものに相当）は、実験か ら得られた最大せん断力 $Q_{\text {exp }}$ （Fig.9の灰色印）を用いて、それぞ $れ_{d p} Q=Q_{e x p}-f_{r} Q$ および ${ }_{d h} Q=Q_{e q}-Q_{\text {exp }}$ として求めることが できる。

一方、補強フレームの保有耐震性能 ( $I_{s}$ 值) は限界層間変位とそ のときの保有層せん断力の積で与えられる。そこで本検討では、 $290 \mathrm{gal}$ 入力に対応する $I_{s}$ 曲線上の応答值を直線補完することによ って限界層間変位 $20 \mathrm{~mm}$.での層せん断力を求め、補強フレームの $I_{s}$ 值を算定した。すなわち、各補強試験体について最大応答時にお ける $\mathrm{RC}$ フレームの負担せん断力 ${ }_{f r} Q$ に対する最大応答実験值 $Q_{\text {exp }}$ の比率 $Q_{\text {exp }} /{ }_{f r} Q$ を求め、限界層間変位 $20 \mathrm{~mm}$ での RC フレ 一ムの強度 (120tonf) に $Q_{\exp } /{ }_{f r} Q$ を乗じて補強フレームの強度 $\left(\left({ }_{f r} C+_{d p} C\right) \cdot W\right)$ を求める。次に、 $Q_{\text {exp }}$ に対する $I_{s}$ 曲線上の応 答推定值 $Q_{e q}$ (等価せん断力）の比率 $Q_{e q} / Q_{e x p}$ (すなわち、 $1 / D_{h}$ ）

\begin{tabular}{|l|c|c|c|c|}
\hline Specimen & Frame only & $\begin{array}{c}\text { Frame } \\
+ \text { Device }\end{array}$ & $\begin{array}{l}\text { Frame } \\
\text { +Device } \\
+ \text { Damping }\end{array}$ & $\begin{array}{l}\text { Assumed capacity } \\
\text { of trames with a } \\
\text { device }\end{array}$ \\
\hline LYP Frame & $\nabla(100)$ & $(120)$ & $\nabla(175)$ & $(210)$ \\
\hline VE-1 Frame & $\nabla(97)$ & $(123)$ & $\nabla(192)$ & $\nabla(237)$ \\
\hline VE-2 Frame & $\Delta(115)$ & $(116)$ & $\Delta(130)$ & $\Delta(136)$ \\
\hline \multicolumn{4}{|c|}{ N : Capacity of RC frame in specimens with a device } \\
\hline \multicolumn{2}{|c|}{ Note: The numerical in parenthesis for each mark shows the value of shear. }
\end{tabular}
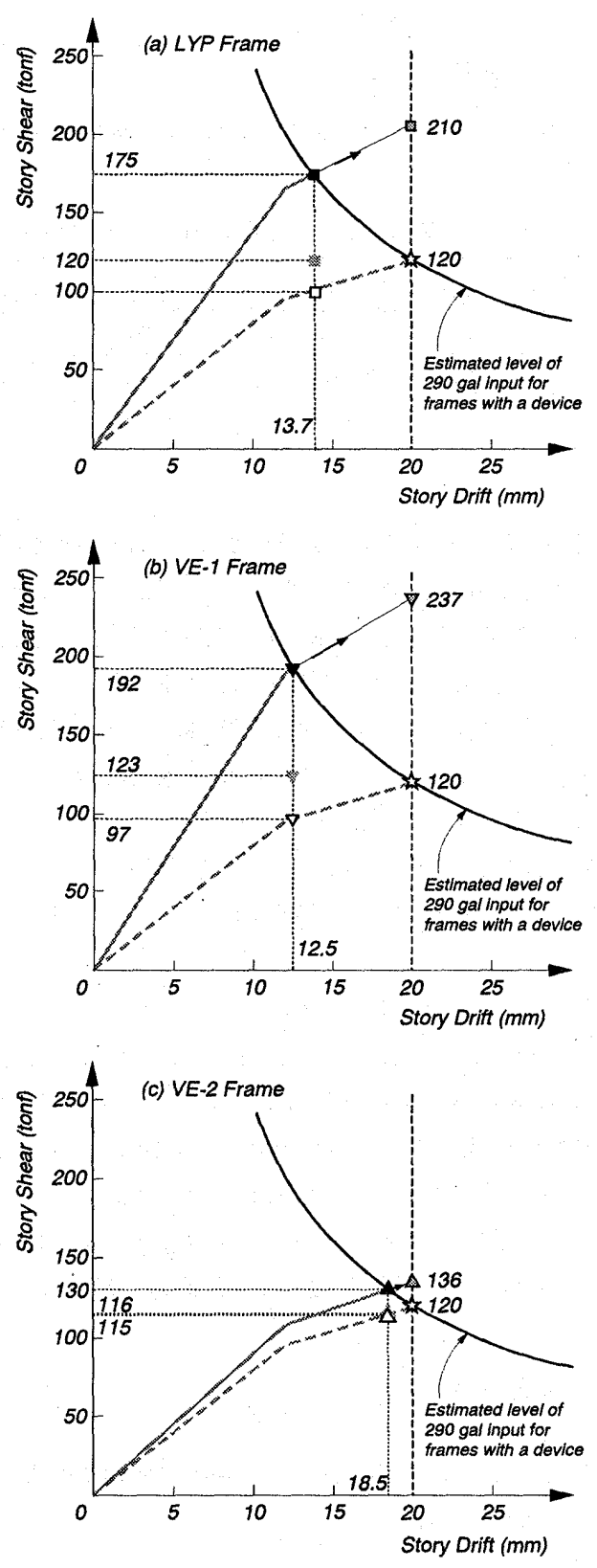

Fig. 9 Estimation of $I_{s}$ Based on Test Results 

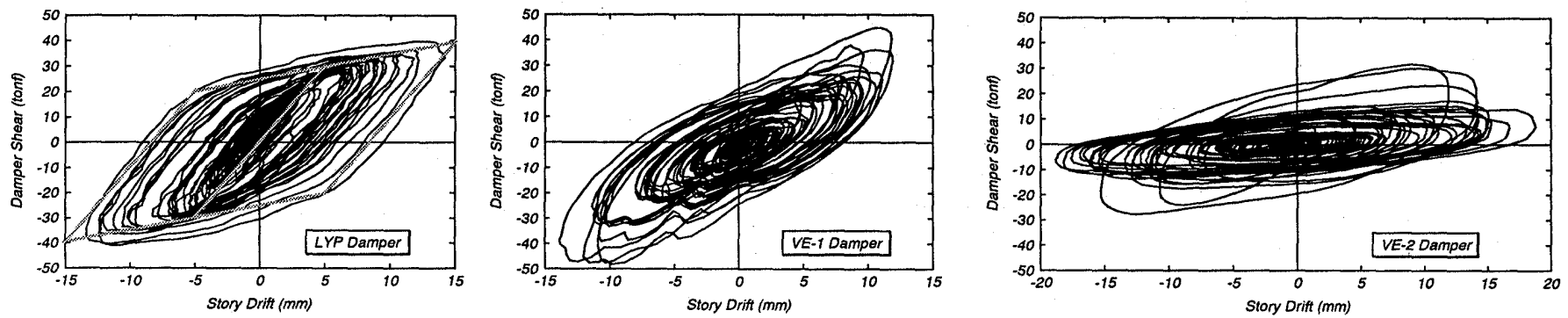

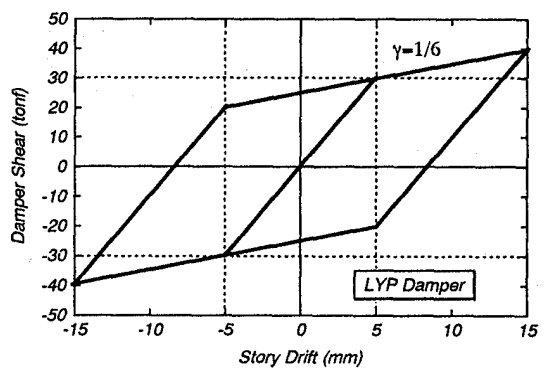

(a) LYP Frame

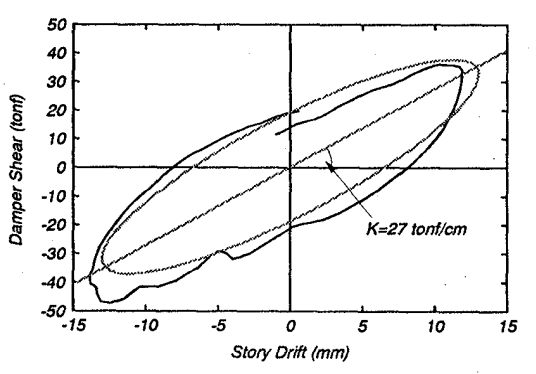

(b) VE-1 Frame

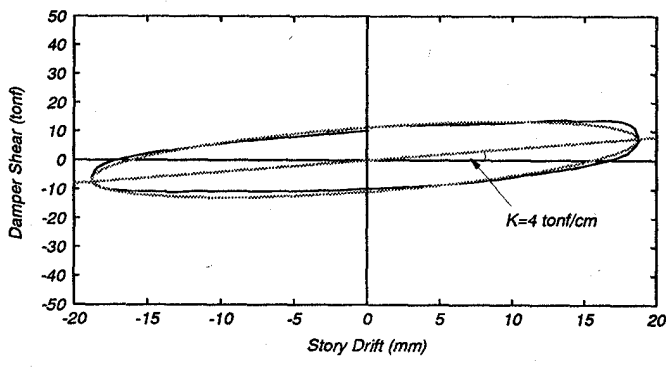

(c) VE-2 Frame

Fig. 10 Shear versus Story Drift Relations and Their Modeling for Energy Absorbing Devices

Table $3 I_{s}$ Values Calculated by Proposed Method

\begin{tabular}{c||c|c|c|c|c}
\hline Specimen & ${ }_{f_{r}} C+{ }_{d p} C$ & ${ }_{d p} h$ & $D_{h}$ & $I_{\text {scal }}$ & $I_{\text {sexp }} / I_{\text {scal }}$ \\
\hline \hline LYP & 0.654 & 0.044 & 0.773 & 0.846 & 1.13 \\
\hline VE-1 & 0.690 & 0.056 & 0.727 & 0.949 & 1.13 \\
\hline VE-2 & 0.550 & 0.007 & 0.957 & 0.575 & 1.07 \\
\hline
\end{tabular}

を求め、それを限界層間変位での補強フレームの強度に乗じること によって保有層せん断力を算定した。Fig.9は以上の算定過程を層せ ん断力ー層間変形関係と $I_{s}$ 曲線を用いて図式的に説明したもので ある。また、各補強フレームの実験結果から推定した $I_{s}$ 值を Table 2 に示す。 $I_{s}$ 值の算定においては、前述したように限界層間変位 $20 \mathrm{~mm}$ を $F=1.0$ と仮定し、さらに保有層せん断力を慣性重量 (220tonf) で除することによって $C$ 值を求めている。なお、同表 には参考として、実験結果から推定した減衰補正係数 $D_{h \text { exp }}$ $\left(=\left({ }_{f r} C+_{d p} C\right) /\left({ }_{f r} C+_{d p} C+{ }_{d h} C\right)\right)$ も併せて示している。

\section{2 提案手法による補強フレームの $I_{s}$ 計算値}

各試験体の最大応答時における等価粘性減衰定数を Fig.10に示 す各試験体の実験から得られたエネルギー吸収デバイスの負担せ ん断力一層間変位関係に基づいて求める。同図(a)より、LYP 補強フ レームにおけるデバイスの二次剛性低下率 $\gamma$ および最大応答変位 時の塑性率 ${ }_{d p} \mu$ はそれぞれ $\gamma \approx 1 / 6$ および ${ }_{d p} \mu \approx 4$ と仮定できる。 したがって、最大応答変位時の強度の降伏耐力に対する比率 $\alpha$ は式 (8)より

$$
\alpha=1+(4-1) / 6=1.5
$$

となり、さらに、式(12)よりダンパーの等価粘性減衰定数 ${ }_{d p} h_{L Y P}$ が 以下のように求められる。

$$
{ }_{d p} h_{L Y P}=\frac{2}{\pi} \times \frac{4-1.5}{4 \times 1.5}=0.265
$$

一方、Fig.10 (b)および(c)より、VE-1補強フレームおよび VE-2 補強フレームのそれぞれのダンパーをモデル化した履歴曲線の面 積と等価剛性より、等価粘性減衰定数 ${ }_{d p} h_{V E-1}$ および ${ }_{d p} h_{V E-2}$ がそ れぞれ以下のように与えられる。

$$
\begin{aligned}
& { }_{d p} h_{V E-1}=\frac{1}{4 \pi} \times \frac{76.8}{22.8}=0.268 \\
& { }_{d p} h_{V E-2}=\frac{1}{4 \pi} \times \frac{63.6}{6.85}=0.739
\end{aligned}
$$

したがって、Table 2における各試験体の RC フレームおよびエ ネルギー吸収デバイスの $I_{s}$ 值を用いれば、式(13) (or (15)）および (6)から補強フレームの等価粘性減衰定数 $d p h$ および減衰補正係数 $D_{h}$ が求められ、式(3)より補強フレームの $I_{s}$ 值が計算できる。

Table 3に各試験体に対する ${ }_{f r} C+{ }_{d p} C$ (強度指標)、 ${ }_{d p} h 、 D_{h}$ お よび計算 $I_{s}$ 值をそれぞれ示す。また、同表には Table 2に示した推 定 $I_{s}$ 值の計算 $I_{s}$ 值に対する比率も併せて示している。計算 $I_{s}$ 值は 実験から得られた推定 $I_{s}$ 值に対して若干小さめの值となっている が、各試験体共に概ね両者はよい対応を示しており、本検討の範囲 内では、提案した耐震診断手法は妥当なものであると考えられる。 なお、計算 $I_{s}$ 值が推定 $I_{s}$ 値に対して若干小さめの值となっている のは、Table 2および3からも明らかなように、本検討の範囲では計 算で用いた減衰補正係数 $D_{h}$ が実験結果から推定した減衰補正係数 $D_{\text {hexp }}$ に対して若干大きめの評価となっているためである。

\section{5. 多層建築物における等価粘性減衰定数の評価}

耐震診断基準7)では、構造耐震指標 $I_{s}$ は建築物の各層に対して与 えられる。したがって、本論で提案したエネルギ一吸収デバイスを 用いた建築物の耐震診断手法における $I_{s}$ 値（式(3)）も層に对する ものと考えてよい。しかしながら、式(3)における滅衰補正係数 $D_{h}$ は 建築物全体に対するものでなければならない。そこで、重み平均減 衰9の考え方に基づき、 $N$ 層建築物全体の等価粘性隇哀定数 ${ }_{F} h_{e q}$ は、 
次式で与えられるものとする。

$$
{ }_{F} h_{e q}=\frac{1}{4 \pi} \cdot \frac{\sum_{i=1}^{N} \Delta W_{i}}{\sum_{i=1}^{N} W_{i}}=\frac{\sum_{i=1}^{N} d p C_{i} \cdot F_{i} \cdot d p h_{D e v, i}}{\sum_{i=1}^{N}\left({ }_{f r} C_{i}+{ }_{d p} C_{i}\right) F_{i}}
$$

ここで、 ${ }_{d p} h_{D e v, i}$ は $i$ 層におけるエネルギ一吸収デバイスの等価 粘性減衰定数を表す。

ただし、4章では、1層試験体に対して ${ }_{F} h_{e q}$ が5\%前後の範囲で 式(3)の妥当性を確認したに過ぎない。また、式(6)は応答スペクトル に対する減衰補正係数式として一般的なものであり、等価粘性減衰 定数が $10 \%$ 程度以下の比較的小さな場合に良好な補正精度を与え るが、それ以上の場合には過大補正となる傾向がある。したがって、 式(6)で $D_{h}$ を評価し、式(3)により構造耐震指標を算定する本手法の 場合、 ${ }_{F} h_{e q}$ の上限值（換言すれば、 $D_{h}$ の下限值）を適切に設定す る必要があると考えられる。また、 $F_{e q}$ の大きさに応じて式(6)と は異なる適切な隇衰補正式を用いることも一方法であろう。これら については今後の検討課題としたい。

なお、本論で行った考察は地震動の継続時間がある程度長い場合 を想定しており、建築物が断層のごく近傍にあり、これに継続時間 の短い衙撃的な地震動が作用する場合は想定していない。このよう な問題については、地震動特性から構造物の振動現象まで含めて、 今後の調查研究に待つところが多いと考えられる。

\section{6. $I_{s}$ 值を用いた改修建築物の酎震性能評価フロー}

以下に、エネルギー吸収デバイスを用いた改修建築物の構造耐震 指標 $I_{s}$ による耐震性能評価手順を示す。

(1) 補強前の建築物における各層の $I_{s}$ 値を算定し、補強の要否を 判定する。

(2) エネルギー吸収デバイスを用いて補強を施す層（以下、デバ イス補強層と略記）に対して勒性指標を $F=1.0$ として再度 $I_{s}$ 值を算定する。

(3) ステップ(2)の算定結果に基づいて、目標構造耐震指標 $I_{s o}$ に 対する必要デバイスの強度指標 ${ }_{d p} C_{r e q}$ を次式によって算定 する。

$$
{ }_{d p} C_{r e q}=D_{h} \cdot I_{s o}-I_{s}
$$

ここで、減衰補正係数 $D_{h}$ は暫定的に0.8としてよい。なお、 $D_{h}=0.8$ は(6)式において ${ }_{d p} h$ を3.75\%としたことに相当し、 暫定值として比較的控えめな值を設定したに過ぎない。

(4) 補強後の建築物各層の構造耐震指標を式(3)より算定する。こ のとき、減衰補正係数 $D_{h}$ の算定には式(16)より求めた建築 物全体の等価粘性減衰定数 ${ }_{F} h_{e q}$ を用いる。

(5) ステップ(4)で求めた各層の構造耐震指標 $I_{s}$ が目慗構造耐震 指標 $I_{s o}$ を上回っていることを確認する。 $I_{s} \geq I_{s o}$ を満足し ない場合には、暫定 $D_{h}$ をステップ(4)で求めた值として、ス テップ(3)に戻って再度補強量を算定する。

\section{7. まとめ}

エネルギー吸収デバイスによつて耐震補強を施した鉄筋コンク リート造建築物の耐震性能を構造耐震指標 ( $I_{s}$ 指整)を用いて評価
する方法を示した。また、1971年以前の耐震基準によって設計さ れた5層鉄筋コンクリート建築物の 2 首部分を模擬した実大 1 層 1 ス パンの振動台実験結果を用いて、評価法の妥当性を検証した。得ら れた結果を以下に要約する。

1) $I_{s}$ 指標は補強前之後で建築物の変形能力 ( $F$ 指標) が変化し ないという条件で、補強前の強度指標 ${ }_{f r} C$ と補強デバイスに よる強度指標 ${ }_{d p} C$ およびデバイスによる減衰効果 $D_{h}$ を用い て式(3)で与えられる。

2) 極低降伏点鋼デバイスおよび粘弾性デバイスで補強した振動 実験用試験体3体に対して、提案手法による計算值 $I_{s c a l}$ と実験 結果に基づいた推定值 $I_{s \exp }$ を比較した結果、 $I_{\text {sexp }} / I_{\text {scal }}$ は 1.07〜1.13の範囲にあり、評価法による予測精度が良好であ ることが確認された。

3) 本評価法では、建筑物全体の等価粘性減衰定数 ${ }_{F} h_{e q}$ が大きな 範囲で構造酎震指標を過大評価する傾向が懸念される。したが って、デバイスによる減衰勃果 $D_{h}$ を評価する際、 ${ }_{F} h_{e q}$ の上 限值を適切に設定する必要がある。今後の課題である。

\section{謝 辞}

本研究は、建築研究所、日本建築センター、建築業協会等の共同 研究で実施された「新技術による既存建築物の耐震性向上技術の開 発」(委員長 : 小谷俊介・東京大学教授) の一環として行われたも のであり、同応答制御分科会（主查: 和田章・東京工業大学教授） において貴重なご指摘、ご意見を頂戴した。委員各位に深甚なる謝 意を表する次第である。

\section{参考文献}

1) 建設省住宅局建築指導課監修：「建築物の耐震改修の促進に関する法律」 の法令及びその解説、（財）日本建築防災協会、（財）日本建築セン夕 一、1996年1月、91pp.

2) 建設省建築研究所、他 : 共同研究「新技術による既存建策物の耐震性向 上技術の開発」成果報告書、1999年3月

3)（社）日本コンクリートエ学協会 : 耐震補強の評価に関する研究委員会 報告書・論文集、2000年6月、592pp.

4) 北嶋圭二、他: ダンパーを用いた既存 RC 造建物の耐震補強法に関する研 究 (その 6) 、日本建築学会大会学術講演梗概集、C-2、構造系IV、1997 年 9 月、pp.569-570

5) 坂本光雄 : 応答制御を意図した耐震改修工法 -制震改修-、建筑技術、 No.596、1999年10月、pp.154-157

6) 荻田英之、他 : 制震ブレースを用いた公共建築物の耐震改修、建築技術、 No.581、1998年7月、pp.154-157

7) 国土交通省住宅局建策指導課監修: 2001年改訂版 既存鉄筋コンクリー 卜造建築物の耐震診断基準・同解説、（財）日本建築防災協会、2001年 10月、300pp.

8) 飯塚信一、他 : エネルギー吸収部材を用いた既存建筑物の耐震改修効果 に関する研究 (その1〜4)、日本建築学会大会学術講演梗概集、C-2、 構造系I、1999 年 9 月、pp.165-172

9) 柴田明徳 : 最新耐震構造解析、最新建策学シリーズ9、森北出版、1981 年6月、342pp.

10)'秋山宏、他 : 慣性加力装置を用いた構造要素の実大振動台実験方法、日 本建箱学会構造系論文集、第505号、1998年3月、pp,139-146

11）饭場正紀、稲井栄一、倉本 洋: 旧耐震基準で設計された RC 造建築物を 対象とした実大部分架構の動的破壞実験、日本建築学会構造系論文集、 第554号、2002年4月、pp.101-108

（2002年 2 月 25 日原稿受理，2002年 7 月 1 日採用決定） 